\title{
ANALISIS KINERJA KEUANGAN PERUSAHAAN LQ45 YANG TERDAFTAR DI BURSA EFEK INDONESIA
}

\author{
Pitter Leiwakabessy \\ Jurusan Akuntansi Universitas Victory Sorong, \\ e-mail :pitterleiwakabessy@unvicsorong.ac.id
}

\begin{abstract}
Abstrak
Tujuan dari penelitian ini adalah untuk mengidentifikasi laporan keuangan perusahaan LQ45 yang terdaftar di Bursa Efek Indonesia, menganalisis kinerja keuangan pada perusahaan dan memberikan referensi pada investor dalam menentukan pilihan untuk mengembangkan investasinya. Perusahaan LQ45 yang teridentifiksai laporan keuangan,perusahaan yang bertahan dalam periode tahun 2014 sampai dengan tahun 2017 ada 36 perusahaan 5 diantaranya yaitu PT. Telekomunikasi Indonesia Tbk (TLKM), PT. Unilever Indonesia Tbk ( UNVR), PT. Astra Agro Lestari Tbk (ALLI), PT. Adhi Karya (Persero) Tbk (ADHI), PT. Media Nusantara Citra Tbk (MNCN). Kinerja setiap perusahaan berdasarkan rataan Return on Total Asset / Return On Investment (ROI) dalam 4 tahun terakhir, perusahaan yang berada pada posisi tertinggi dengan nilai sebesar 0,377 adalah perusahaan PT Unilever Indonesia Tbk (UNVR), sedangkan yang berada pada posisi terendah adalah PT Adhi Karya (Persero) Tbk (ADHI) dengan nilai sebesar 0,012. Kondisi pertumbuhan per tahun pada perusahaan UNVR sebesar $-7 \%,-5 \%, 6 \%$, sedangkan kondisi pertumbuhan per tahun pada perusahaan ADHI adalah sebesar -91\%, 1494\%, $16 \%$.
\end{abstract}

Kata kunci : Laporan Keuangan, Perusahaan LQ45.

\section{PENDAHULUAN}

Kegiatan investasi pada hakekatnya memiliki motif yang sama yaitu untuk mendapatkan keuntungan atau laba dalam jumlah tertentu. Motif mencari keuntungan merupakan hal yang paling mendasar (Primary Motif), yang membedakan kegiatan investasi (Investment) dengan kegiatan menabung (Saving) adalah untuk proteksi/perlindungan serta untuk memperoleh rasa aman melalui tindakan berjaga-jaga dengan mencadangkan sejumlah dana. Dalam melaksanakan kegiatan investasi, seorang investor selalu dihadapkan pada dua hal yaitu tingkat keuntungan/pengembalian (return) dan juga resiko yang mungkin timbul akibat adanya ketidakpastian (uncertainty).

Menteri Keuangan Sri Mulyani Indrawati mengatakan, meski ekonomi dunia masih diliputi ketidakpastian, namun perekonomian Indonesia relatif lebih baik. Hal tersebut, kata Ani ditandai dengan pertumbuhan ekonomi Indonesia dalam 10 tahun terakhir bisa mencapai angka $\quad 5,7 \%$ bila dirata-rata. "Pertumbuhan ekonomi kita jika diratarata 10 tahun terakhir yakni 5,7\%, tertinggi kalau dibanding emerging market di dunia," kata Ani dalam rapat kerja Kementerian Keuangan, di kantornya, Jakarta Pusat, Selasa (10/1/2017). Dalam forum tersebut, dirinya menjelaskan bila pertumbuhan 
ekonomi Indonesia mulai melemah pada

2014 menuju 2015. Data menunjukkan:

Tabel 1.

\begin{tabular}{|c|c|c|c|}
\hline \multirow{2}{*}{ Kuartal } & \multicolumn{3}{|c|}{ Tahun } \\
\cline { 2 - 4 } & 2014 & 2015 & 2016 \\
\hline Pertama & $5,14 \%$ & $4,71 \%$ & $4,92 \%$ \\
\hline Kedua & $5,03 \%$ & $5,18 \%$ & $5,18 \%$ \\
\hline Ketiga & $4,92 \%$ & $4,73 \%$ & $5,02 \%$ \\
\hline Keempat & $5,01 \%$ & $5,04 \%$ & $5,1 \%$ \\
\hline
\end{tabular}

RUMUSAN MASALAH

"Setelah 2014, 2015, 2016 masih early recovery, sehingga kita hati - hati men-design pertumbuhan 2017". Dari data pertumbuhan pereekonomian Indonesia yang naik turun tersebut juga mempengaruhi kapitalisasi pasar

perusahaan - perusahaan LQ45 yang telah terdaftar di Bursa Efek Indonesia (BEI). Dimana dari total 45 perusahaan yang di LQ45 hanya ada 36 perusahaan yang dapat bertahan dari Agustus 2014 sampai dengan Juli 2017.

Berdasarkan latar belakang yang diuraikan diatas,maka permasalahan yang di teliti berkaitan dengan perkembangan suatu perusahaan dapat diketahui melalui kondisi keuangan perusahaan,salah satu cara yang dapat dipelajari adalah laporan keuangan perusahaan tersebut. Hal ini bisa menjadi masalah bagi para investor apabila tidak mengetahui prospek

keuntungan dimasa yang akan datang untuk menentukan investasi yang tepat dan penanaman modal pada perusahaan yang tetap bertahan dalam kondisi ekonomi yang berubah-ubah. Tidak semua investor memiliki akses untuk bisa mengetahui perkembangan kondisi keuangan suatu perusahaan dan memperoleh kemudahaan untuk memahami hal tersebut.

Dari uraian tersebut peneliti tertarik melakukan penelitian yang dituang dalam penyusunan skripsi dengan judul : "Analisis Kinerja Keuangan Perusahaan LQ45 Yang Terdaftar DI Bursa Efek Indonesia".
Berdasarkan dari latar belakang diatas maka perumusan masalah yang akan dibahas dalam penelitian ini adalah : Bagaimana kinerja keuangan pada perusahaan yang terdaftar di Index LQ45

\section{TINJAUAN PUSTAKA}

\section{A. Pasar Modal}

Undang-Undang Republik Indonesia No.8 Tahun 1995 mengemukakan bahwa efek adalah surat berharga, yaitu surat pengakuan hutang, surat berharga komersial, saham, obligasi, tanda bukti hutang, unit penyetoran kontrak investasi kolektif, kontrak berjangka atas efek dan setiap derivatif dari efek. Sedangkan pengertian Bursa Efek merupakan sebuah pasar yang terorganisi dimana para pialang melakukan transaksi jual beli saham / surat berharga dengan berbagai perangat aturan yang ditetapkan oleh Bursa Efek Indonesia (BEI). Bursa Efek merupakan tempat pertemuan pencari modal dengan pihak yang memiliki uang dengan tujuan investasi. Fungsi Bursa Efek ini antara lain adalah pertama, menjaga kontinuitas pasar. Kedua, menciptakan harga efek yang wajar melalui mekanisme permintaan dan penawaran.

\section{B. Investasi}

Investasi adalah penanaman modal untuk biasanya berjangka panjang dengan harapan mendapatkan keuntungan di masa yang akan datang sebagai kompensasi secara professional atas penundaan konsumsi, dampak inflasi dan resiko yang 
di tanggung. Keputusan investasi dapat dilakukan individu,dari investasi tersebut dapat berupa capital gain/los dan yield.

\section{C. $\mathbf{Q Q 4 5}$}

LQ45 adalah kumpulan 45 sahamsaham yang mempunyai likuiditas yang tinggi atau sering ditransaksikan dan biasanya manajer investasi akan menempatkan dananya pada saham-saham yang termasuk dalam LQ45 untuk mengurangi resiko likuiditas. LQ45 juga dianggap sebagai bencmark untuk menilai suatu kinerja investasi berbasis pasar modal. Saham-saham pada indeks LQ45 harus memenuhi kriteria dan melewati seleksi utama sebagai berikut:

1. Masuk dalam ranking 60 besar dari total transaksi saham di pasar regular (rata-rata nilai transaksi selama 12 bulan terakhir).

2. Rangking berdasarkan kapitalisasi pasar (rata-rata kapitalisasi pasar selama ( 23 bulan terakhir).

3. Telah tercatat di BEI minimum 3 bulan.

4. Keadaan keuangan perusahaan dan prospek pertumbuhannya, frekuensi.

\section{METODOLOGI PENELITIAN}

\section{A. Lokasi Dan Objek Penelitian}

1. Lokasi Penelitian

Lokasi penelitian yang dilakukan dalam rangka penulisan skripsi ini yaitu Kantor perwakilan BEI (Bursa Efek Indonesia) yang terdapat di Papua Barat. Yang beralamat di Jl. Trikora Wosi No. 86, Kel. Wosi, Kec. Manokwari Barat, Kab. Manokwari, Papua Barat.

2. Objek Penelitian

Objek dari penelitian ini adalah Analisis Kinerja Keuangan 10 Perusahaan LQ45 yang terdaftar di BEI.

\section{B. Teknik Pengumpulan Data}

Metode yang digunakan untuk mendapatkan data yang diinginkan adalah sebagai berikut : Observasi tidak langsung Dilakukan dengan membuka Website dari objek yang diteliti, sehingga dapat diperoleh laporan serta gambaran umum Perusahaan LQ45 yang terdaftar di BEI. Studi pustaka adalah pengumpulan data dengan cara mempelajari dan memahami buku-buku yang mempunyai hubungan dengan Laporan Keuangan, Pasar Modal, saham dan hasil penelitian yang diperoleh dari berbagai sumber, baik dari perpustakaan dan sumber lain.

\section{Metode Analisis}

Analisis rasio keuangan yang di gunakan dalam penelitian skripsi ini adalah:

1. Profitabilitas Ratio (Rasio Keuntungan)

2. Profit Margin on Sales $=\frac{\text { laba bersih }}{\text { total aktiva }}$

3. Return on Total Asset (ROA)

4. Rasio Pengembalian Modal (return on net worth)

HASIL DAN PEMBAHASAN

Analisis Laporan Keuangan 5 Perusahaan LQ45

Pembahasan selanjutnya adalah membandingkan laporan keuangan dari 5 perusahaan yang menjadi sampel penelitian. Laporan keuangan terdiri dari :

a. Laporan keuangan laba rugi per tahun dan dihitung pertumbuhan per tahun berdasarkan rata-ratanya tahun 2014 sampai tahun 2017;

b. Laporan keuangan laba operasi bersih sesudah pajak serta pertumbuhan dan rata-ratanya dari tahun 2014 sampai 2017;

c. laporan keuangan kewajiban (hutang) serta pertumbuhan dan rata-ratanya dari tahun 2014 sampai tahun 2017 
d. Laporan modal (ekuitas) serta pertumbuhan dan rata-ratanya dari tahun 2014 sampai tahun 2017;

e. Laporan aktiva (asset) serta pertumbuhan dan rata-ratanya dari tahun 2014 sampai tahun 2017. Hasil olah data dan perhitungan dibuat dalam bentuk tabel, serta analisis laporan keuangan dari 5 perusahaan LQ45 dibawah ini:

\section{a. Laporan keuangan laba rugi dan pertumbuhan dalam 4 tahun terakhir.}

Tabel 3

Laporan keuangan Laba Rugi dari 5 Perusahaan LQ45 (dalam ribuan rupiah).

\begin{tabular}{|c|c|c|c|c|c|c|}
\hline \multirow{2}{*}{ No } & \multirow{2}{*}{$\begin{array}{c}\text { Kode } \\
\text { Emiten }\end{array}$} & \multicolumn{2}{|c|}{ Tahun } & \multirow{2}{*}{ Rata-Rata } \\
\cline { 3 - 6 } & & $\mathbf{2 0 1 4}$ & $\mathbf{2 0 1 5}$ & $\mathbf{2 0 1 6}$ & $\mathbf{2 0 1 7}$ & \\
\hline 1 & AALI & 3.689 .990 .000 & 1.175 .513 .000 & 2.208 .778 .000 & 2.938 .505 .000 & 2.503 .196 .500 \\
\hline 2 & TLKM & 28.784 .000 .000 & 31.342 .000 .000 & 38.189 .000 .000 & 42.659 .000 .000 & 35.243 .500 .000 \\
\hline & & & & & & \\
3 & UNVR & 7.676 .722 .000 & 7.829 .490 .000 & 8.571 .885 .000 & 9.371 .661 .000 & 8.362 .439 .500 \\
\hline 4 & MNCN & 2.543 .779 .000 & 1.811 .026 .000 & 2.152 .932 .000 & 2.415 .650 .000 & 2.230 .846 .750 \\
\hline 5 & ADHI & 267.662 .496 & 47.215 .659 & 612.622 .455 & 957.281 .629 & 471.195 .560 \\
\hline
\end{tabular}

Sumber data : Data diolah

Berdasarkan Tabel 3 dapat dilihat posisi tertinggi pada rataan laporan laba rugi perusahaan tahun 2014 sampai tahun 2017 sebesar Rp 35.243.500.000.000,- adalah perusahaan PT . Telekomunikasi Indonesia Tbk (TLKM), sedangkan posisi terendah PT. Adhi Karya (Persero) Tbk sebesar Rp. 471.195.560.381,- . Kondisi pertumbuhan laba rugi per tahun pada perusahaan TLKM dari tahun 2014 sampai 2017 adalah 9\%, 22\%, dan 12\%, sedangkan kondisi pertumbuhan perusahaan ADHI adalah $-82 \%, 119 \%$, $56 \%$, . Hal ini menunjukkan bahwa ada perbedaan yang signifikan antara perusahaan TLKM dengan ADHI. Perbedaan pertumbuhan laba rugi per tahun antara 5 perusahaan dapat dilihat pada Tabel 4.

Tabel 4

Pertumbuhan laba rugi per tahun berdasarkan rata-rata tahun 2014 sampai 2017 dari 5 perusahaan LQ45 (dalam Rupiah)

\begin{tabular}{|r|c|c|r|r|r|}
\hline \multirow{2}{*}{ No } & \multirow{2}{*}{$\begin{array}{c}\text { Kode } \\
\text { Emiten }\end{array}$} & 2017 & \multicolumn{3}{|c|}{ Pertumbuhan / tahun } \\
\cline { 4 - 6 } & AALI & 2.503 .196 .500 .000 & $-68 \%$ & $88 \%$ & $33 \%$ \\
\hline 1 & Aata 2014 - & 2015 & 2016 & 2017 \\
\hline 2 & TLKM & 35.243 .500 .000 .000 & $9 \%$ & $22 \%$ & $12 \%$ \\
\hline 3 & UNVR & 8.362 .439 .500 .000 & $2 \%$ & $9 \%$ & $9 \%$ \\
\hline 4 & MNCN & 2.230 .846 .750 .000 & $-29 \%$ & $19 \%$ & $12 \%$ \\
\hline 5 & ADHI & 471.195 .560 .381 & $-82 \%$ & $1197 \%$ & $56 \%$ \\
\hline
\end{tabular}


Sumber data : Data diolah.

Dasar penyusunan laporan keuangan konsolidasian disusun berdasarkan konsep biaya perolehan dan disusun menggunakan metode langsung dan arus kas dikelompokkan atas dasar aktivitas operasi, investasi dan pendanaan. Penyusunan laporan keuangan konsolidasian sesuai dengan prinsip akuntansi yang berlaku umum mengharuskan manajemen untuk membuat estimasi dan asumsi yang mempengaruhi jumlah aktiva dan kewajiban dan pengungkapan aktiva dan kewajiban kontinjensi pada tanggal laporan keuangan konsolidasian serta jumlah pendapatan dan beban selama periode pelaporan.

\section{b. Laba Operasi Bersih Sesudah Pajak (NOPAT) dan pertumbuhan dalam 4 tahun terakhir.}

Pajak penghasilan badan dihitung untuk setiap perusahaan sebagai badan hukum yang berdiri sendiri. Semua perbedaan temporer antara jumlah tercatat aktiva dan kewajiban dengan dasar pengenaan pajaknya diakui sebagai pajak

Tabel 5

Net Operating After Tax (NOPAT) 5 perusahaan LQ45 (dalam ribuan rupiah)

\begin{tabular}{|c|c|c|c|c|c|c|}
\hline \multirow{2}{*}{ No } & \multirow{2}{*}{$\begin{array}{c}\text { Kode } \\
\text { Emiten }\end{array}$} & \multicolumn{4}{|c|}{ Tahun } & \multirow{2}{*}{ Rata-rata } \\
\cline { 5 - 7 } & 2014 & 2015 & 2016 & 2017 & \\
\hline 1 & AALI & 2.621 .275 .000 & 695.684 .000 & 2.114 .299 .000 & 2.113 .629 .000 & 1.886 .221 .750 \\
\hline 2 & TLKM & 21.446 .000 .000 & 23.317 .000 .000 & 29.172 .000 .000 & 32.701 .000 .000 & 26.659 .000 .000 \\
\hline 3 & UNVR & 5.738 .523 .000 & 5.864 .386 .000 & 5.957 .507 .000 & 7.107 .230 .000 & 6.166 .911 .500 \\
\hline 4 & MNCN & 1.883 .432 .000 & 1.407 .216 .000 & 1.482 .955 .000 & 1.567 .546 .000 & 1.585 .287 .250 \\
\hline 5 & ADHI & 102.051 .534 & 10.793 .511 & 315.107 .783 & 517.059 .848 & 236.253 .169 \\
\hline
\end{tabular}

Sumber data : Data diolah.

Berdasarkan tabel 5 dapat dilihat posisi tertinggi pada rataan NOPAT adalah PT. Telekomunikasi Indonesia Tbk (TLKM) yaitu sebesar Rp. 26.659.000.000.000,- , tangguhan. Tarif pajak yang berlaku saat ini dipakai untuk menentukan pajak tangguhan. Pengakuan pajak tangguhan atas perbedaan temporer dan akumulasi rugi fiskal yang masing-masing dapat berupa aktiva atau kewajiban disajikan dalam jumlah bersih untuk masingmasing entitas yang dikonsolidasikan. Aktiva pajak tangguhan diakui apabila besar kemungkinan bahwa jumlah laba fiskal pada masa mendatang akan memadai untuk dikompensasi dengan saldo rugi fiskal dan perbedaan temporer yang dapat dikurangkan. 
TLKM adalah 9\%, 25\%, dan 12\%, Sedangkan kondisi NOPAT perusahaan ADHI adalah $-89 \%$, 2819\%, dan $64 \%$. Perbedaan pertumbuhan NOPAT per tahun antara 5 perusahaan dapat dilihat pada tabel 6 .

\section{Tabel 6}

Pertumbuhan NOPAT per tahun berdasarkan rataan tahun 2014 sampai tahun 2017 dari 5 perusahaan LQ45 (dalam Rupiah).

\begin{tabular}{|c|c|c|c|c|c|}
\hline \multirow{2}{*}{ No } & \multirow{2}{*}{$\begin{array}{c}\text { Kode } \\
\text { Emiten }\end{array}$} & Rata - rata 2014-2017 & \multicolumn{3}{|c|}{ Pertumbuhan / tahun } \\
\cline { 4 - 6 } & & 2015 & 2016 & 2017 \\
\hline 1 & AALI & 1.886 .221 .750 .000 & $-73 \%$ & $204 \%$ & $-0,03 \%$ \\
\hline 2 & TLKM & 26.659 .000 .000 .000 & $9 \%$ & $25 \%$ & $12 \%$ \\
\hline 3 & UNVR & 6.166 .911 .500 .000 & $2 \%$ & $2 \%$ & $19 \%$ \\
\hline 4 & MNCN & 1.585 .287 .250 .000 & $-25 \%$ & $5 \%$ & $6 \%$ \\
\hline 5 & ADHI & 236.253 .169 .285 & $-89 \%$ & $2819 \%$ & $64 \%$ \\
\hline
\end{tabular}

Sumber data : Data diolah.

\section{c. Kewajiban (Hutang) dan pertumbuhan dalam 4 tahun terakhir}

Tabel 7

Kewajiban (Hutang) dari 5 perusahaan LQ45 (dalam ribuan rupiah)

\begin{tabular}{|c|c|c|c|c|c|c|}
\hline \multirow{2}{*}{ No } & \multirow{2}{*}{$\begin{array}{c}\text { Kode } \\
\text { Emiten }\end{array}$} & \multicolumn{4}{|c|}{ Tahun } & \multirow{2}{*}{ Rata-rata } \\
\hline & & 2014 & 2015 & 2016 & 2017 & \\
\hline 1 & AALI & 6.720 .843 .000 & 9.813.584.000 & 6.632 .640 .000 & 6.398 .988 .000 & 7.391.513.750 \\
\hline 2 & TLKM & 54.770 .000 .000 & 72.745 .000 .000 & 74.067 .000 .000 & 86.354 .000 .000 & 71.984 .000 .000 \\
\hline 3 & UNVR & 9.681 .888 .000 & 10.902 .585 .000 & 12.041 .437 .000 & 13.733 .025 .000 & 11.589 .733 .750 \\
\hline 4 & $\mathrm{MNCN}$ & 4.215 .820 .000 & 4.908.164.000 & 4.752 .769 .000 & 5.256 .208 .000 & 4.783.240.250 \\
\hline 5 & ADHI & 1.578.704.059 & 1.664.263.339 & 1.608.287.449 & 4.829.741.347 & 2.420.249.048 \\
\hline
\end{tabular}

Sumber data : Data diolah

Berdasarkan tabel 7 dapat dilihat posisi tertinggi rata-rata kewajiban (hutang) perusahaan pada tahun 2014 sampai 2017 adalah perusahaan PT. Telekomunikasi Indonesia Tbk (TLKM) sebesar Rp 71.984.000.000.000,- sedangkan yang terendah adalah perusahaan PT. Adhi Karya (Persero) Tbk sebesar
Rp.2.420.249.048.966,- _ . Kondisi kewajiban (hutang) per tahun pada perusahaan TLKM adalah $33 \%, 2 \%$, dan $17 \%$, sedangkan pada perusahaan ADHI adalah 5\%, $-3 \%$, dan 200\%. Perbedaan pertumbuhan kewajiban (hutang) per tahun antara 5 perusahaan LQ45 dapat dilihat pada tabel 8

Tabel 8

Pertumbuhan Kewajiban (hutang) per tahun berdasarkan rataan tahun 2014 sampai tahun 2017 dari 5 perusahaan LQ45 (dalam Rupiah). 


\begin{tabular}{|c|c|c|r|r|r|}
\hline \multirow{2}{*}{ No } & \multirow{2}{*}{$\begin{array}{c}\text { Kode } \\
\text { Emiten }\end{array}$} & Rata - rata 2014-2017 & \multicolumn{3}{|c|}{ Pertumbuhan / tahun } \\
\cline { 4 - 6 } & & 2015 & 2016 & 2017 \\
\hline 1 & AALI & 7.391 .513 .750 .000 & $46 \%$ & $-32 \%$ & $-4 \%$ \\
\hline 2 & TLKM & 71.984 .000 .000 .000 & $33 \%$ & $2 \%$ & $17 \%$ \\
\hline 3 & UNVR & 11.589 .733 .750 .000 & $13 \%$ & $10 \%$ & $14 \%$ \\
\hline 4 & MNCN & 4.783 .240 .250 .000 & $16 \%$ & $-3 \%$ & $11 \%$ \\
\hline 5 & ADHI & 2.420 .249 .048 .966 & $5 \%$ & $-3 \%$ & $200 \%$ \\
\hline
\end{tabular}

Sumber data : Data diolah.

\section{d. Modal (Ekuitas Pemilik) dan pertumbuhan dalam 4 tahun terakhir}

Tabel 9

Modal (Ekuitas Pemilik) 5 perusahaan LQ45 (dalam ribuan rupiah)

\begin{tabular}{|c|c|c|c|c|c|c|}
\hline \multirow{2}{*}{ No } & \multirow{2}{*}{$\begin{array}{c}\text { Kode } \\
\text { Emiten }\end{array}$} & \multicolumn{4}{|c|}{ Tahun } & \multirow{2}{*}{ Rata-rata } \\
\hline & & 2014 & 2015 & 2016 & 2017 & \\
\hline 1 & AALI & 11.419 .406 .000 & 11.284 .816 .000 & 17.135 .284 .000 & 18.065 .943 .000 & 14.476 .362 .250 \\
\hline 2 & TLKM & 67.807 .000 .000 & 75.136 .000 .000 & 84.384 .000 .000 & 92.713 .000 .000 & 80.010 .000 .000 \\
\hline 3 & UNVR & 4.598 .782 .000 & 4.827 .360 .000 & 4.704 .258 .000 & 5.173 .388 .000 & 4.825 .947 .000 \\
\hline 4 & MNCN & 8.906 .773 .000 & 8.965 .797 .000 & 8.818 .137 .000 & 9.024 .688 .000 & 8.928 .848 .750 \\
\hline 5 & ADHI & 1.518 .302 .697 & 1.690 .840 .918 & 5.433 .255 .964 & 5.859 .245 .553 & 3.625 .411 .283 \\
\hline
\end{tabular}

Sumber data : Data diolah.

Berdasarkan tabel 9 dapat dilihat posisi tertingi rata - rata pada Modal (Ekuitas Pemilik) adalah perusahaan PT. Telekomunikasi Indonesia Tbk (TLKM) yaitu sebesar Rp 80.010.000.000.000,- , sedangkan yang berada posisi terendah adalah perusahaan PT. Adhi Karya
(Persero) Tbk (ADHI) yaitu sebesar Rp 3.625,411.283.734,- _ . Kondisi pertumbuhan pada Modal (Ekuitas Pemilik) per tahun pada perusahaan TLKM adalah $11 \%, 12 \%$, dan $10 \%$, sedangkan pada perusahaan ADHI adalah $11 \%$, 221\%, dan $8 \%$.

Tabel 10

Pertumbuhan Modal (Ekuitas Pemilik) per tahun berdasarkan rataan tahun 2014 sampai tahun 2017 dari 5 perusahaan LQ45 (dalam Rupiah).

\begin{tabular}{|c|c|c|c|c|c|}
\hline \multirow{2}{*}{ No } & \multirow{2}{*}{$\begin{array}{c}\text { Kode } \\
\text { Emiten }\end{array}$} & Rata - rata 2014-2017 & \multicolumn{3}{|c|}{ Pertumbuhan / tahun } \\
\cline { 4 - 6 } & & 2015 & 2016 & 2017 \\
\hline 1 & AALI & 14.476 .362 .250 .000 & $-1 \%$ & $52 \%$ & $5 \%$ \\
\hline 2 & TLKM & 80.010 .000 .000 .000 & $11 \%$ & $12 \%$ & $10 \%$ \\
\hline
\end{tabular}




\begin{tabular}{|c|c|c|c|c|c|}
3 & UNVR & 4.825 .947 .000 .000 & $5 \%$ & $-3 \%$ & $10 \%$ \\
\hline 4 & MNCN & 8.928 .848 .750 .000 & $1 \%$ & $-2 \%$ & $2 \%$ \\
\hline 5 & ADHI & 3.625 .411 .283 .734 & $11 \%$ & $221 \%$ & $8 \%$ \\
\hline
\end{tabular}

Sumber data : Data diolah.

\section{e. Total Aset (Total Aktiva) dan} pertumbuhan dalam 4 Tahun Terakhir

Aktiva (assets) adalah sumber daya yang dimiliki oleh perusahaan mencakup kas, tanah, pabrik dan peralatan. Pengembalian suatu perusahaan dapat dinilai dari perspektif dasar pendanaan keseluruhan, yaitu kewajiban ditambah ekuitas, total aktiva. Pengembalian atas total aktiva (return on total asset) merupakan ukuran efisiensi operasi yang relevan. Apabila nilai tercatat dari aktiva lebih besar dari nilai yang dapat diperoleh kembali, nilai tercatat aktiva diturunkan menjadi sebesar nilai yang dapat diperoleh kembali, dimana nilai tersebut ditentukan sebagai nilai tertinggi antara harga jual bersih atau nilai pakai. Apabila aktiva tetap tidak digunakan lagi atau dijual, maka nilai tercatat dan akumulasi penyusutannya dikeluarkan dari laporan keuangan konsolidasian, serta keuntungan dan kerugian yang dihasilkan diakui dalam laporan laba rugi konsolidasian. Aktiva dalam penyelesaian dinyatakan sebesar harga perolehan dan disajikan sebagai bagian dari aktiva tetap. Akumulasi harga perolehan akan direklasifikasi ke masingmasing aktiva tetap pada saat aktiva tersebut selesai dikerjakan dan siap digunakan. Penyusutan mulai dibebankan pada bulan aktiva tersebut mulai digunakan.

Tabel 11

Total Aset (Aktiva) 5 perusahaan LQ45 (dalam ribuan rupiah).

\begin{tabular}{|c|c|c|c|c|c|c|}
\hline \multirow{2}{*}{ No } & \multirow{2}{*}{$\begin{array}{l}\text { Kode } \\
\text { Emiten }\end{array}$} & \multicolumn{4}{|c|}{ Tahun } & \multirow{2}{*}{ Rata-rata } \\
\hline & & 2014 & 2015 & 2016 & 2017 & \\
\hline 1 & AALI & 18.558 .329 .000 & 21.512 .371 .000 & 24.226 .122 .000 & 24.935 .426 .000 & 22.308 .062 .000 \\
\hline 2 & TLKM & 140.895 .000 .000 & 166.173 .000 .000 & 179.611 .000 .000 & 198.484 .000 .000 & 171.290 .750 .000 \\
\hline 3 & UNVR & 14.280 .670 .000 & 15.729 .945 .000 & 16.745 .695 .000 & 18.906 .413 .000 & 16.415 .680 .750 \\
\hline 4 & MNCN & 13.609 .033 .000 & 14.474 .557 .000 & 14.239 .867 .000 & 15.057 .291 .000 & 14.345 .187 .000 \\
\hline 5 & $\mathrm{ADHI}$ & 9.553 .283 .529 & 10.975 .102 .047 & 20.095 .435 .959 & 28.332 .948 .012 & 17.239 .192 .387 \\
\hline
\end{tabular}

Sumber data : Data diolah.

Berdasarkan tabel 11 dapat dilihat posisi tertinggi rata - rata pada Total Aset (aktiva) adalah perusahaan PT. Telekomunikasi Indonesia Tbk (TLKM) sebesar Rp 171.290.750.000.000,- , sedangkan yang berada pada posisi terendah adalah perusahaan PT. Media Citra Nusantara Tbk (MNCN) sebesar Rp 14.345.187.000.000,- . Kondisi pertumbuhan Total Aset (Aktiva) per tahun pada perusahaan TLKM adalah $18 \%, 8 \%$, dan $11 \%$, sedangkan peusahaan MNCN adalah $6 \%,-2 \%$, dan $6 \%$. 
Pertumbuhan Total Aset (Aktiva) per tahun berdasarkan rataan tahun 2014 sampai tahun 2017 dari 5 perusahaan LQ45 (dalam Rupiah).

\begin{tabular}{|r|c|r|r|r|r|}
\hline \multirow{2}{*}{ No } & \multirow{2}{*}{$\begin{array}{c}\text { Kode } \\
\text { Emiten }\end{array}$} & Rata - rata 2014-2017 & \multicolumn{3}{|c|}{ Pertumbuhan / tahun } \\
\cline { 4 - 6 } & & 2015 & \multicolumn{1}{|c|}{2016} & \multicolumn{1}{|c|}{2017} \\
\hline 1 & AALI & 22.308 .062 .000 .000 & $16 \%$ & $13 \%$ & $3 \%$ \\
\hline 2 & TLKM & 171.290 .750 .000 .000 & $18 \%$ & $8 \%$ & $11 \%$ \\
\hline 3 & UNVR & 16.415 .680 .750 .000 & $10 \%$ & $6 \%$ & $15 \%$ \\
\hline 4 & MNCN & 14.345 .187 .000 .000 & $6 \%$ & $-2 \%$ & $6 \%$ \\
\hline 5 & ADHI & 17.239 .192 .387 .268 & $15 \%$ & $83 \%$ & $41 \%$ \\
\hline
\end{tabular}

Sumber data : Data diolah.

\section{Rasio Keuangan}

Hasil perhitungan dana analisis rasio keuangan terhadap Profitabilitas Ratio (Rasio Keuntungan) adalah sebagai berikut:

\section{Profitabilitas Ratio (Rasio Keuntungan)}

Efektivitas setiap perusahaan terlihat dari rasio keuntungan, semakin efektif manajemen mengelola perusahaan, maka semakin besar keuntungan yang diperoleh perusahaan. Hasil akhir setiap perusahaan dalam menjalankan tugas dihitung berdasarkan berbagai bentuk rasio profitabilitas akan dijelaskan di bawah ini.

\section{Profit Margin on Sales}

Kemampuan setiap perusahaan dalam menciptakan laba bersih dari penjualan dengan menbandingkan antara laba bersih dan total aktiva, menunjukkan bahwa perusahaan UNVR mendapatkan laba bersih pada tahun 2014 sebesar 0,402 dan menunjukkan profit margin yang tinggi dari tahun - tahun berikutnya dimana pada tahun 2015 mengalami penurunan sebesar 0,373 dan tahun 2016 sebesar 0,356 akan tetapi ada kenaikan pada tahun 2017 yaitu sebesar 0,376. Perusahaan TLKM mendapatkan laba bersih pada tahun 2017 sebesar 0,164 dan menunjukkan profit margin yang tinggi dari tahun - tahun sebelumnya. Perusahaan AALI, MNCN, dan ADHI mengalami perubahan yang tidak stabil dalam indikator profit margin untuk mencari laba. Perhitungan profit margin on sales setiap perusahaan dapat dilihat pada Tabel 13.

Tabel 13

Hasil perhitungan Profit Margin On Sales

\begin{tabular}{|r|r|r|r|r|r|}
\hline \multirow{2}{*}{ No } & \multirow{2}{*}{$\begin{array}{c}\text { Kode } \\
\text { Emiten }\end{array}$} & 2014 & \multicolumn{4}{|c|}{ Tahun } \\
\cline { 3 - 6 } & AALI & $14 \%$ & $3 \%$ & \multicolumn{1}{c|}{2016} & \multicolumn{1}{c|}{2017} \\
\hline 1 & TLKM & $15 \%$ & $14 \%$ & $16 \%$ & $8 \%$ \\
\hline 2 & UNVR & $40 \%$ & $37 \%$ & $36 \%$ & $38 \%$ \\
\hline 3 & MNCN & $14 \%$ & $9 \%$ & $10 \%$ & $10 \%$ \\
\hline 4 & ADHI & $1 \%$ & $0,1 \%$ & $2 \%$ & $2 \%$ \\
\hline 5
\end{tabular}

Sumber data : Data diolah 
2. Return On Total Asset (ROA) / Return On Invesment (ROI)

Berdasarkan hasil perhitungan menunjukkan bahwa tingkat pengembalian (imbalan hasil) yang diperoleh dari suatu investasi atau tingkat efektivitas dari keseluruhan operasi perusahaan sama dengan hasil perhitungan Profit Margin on Sales. Jadi efektivitas perusahaan dalam memanfaatkan sumber ekonomi yang ada, guna menciptakan laba merupakan perbandingan antara laba bersih dengan total asset (aktiva) mengalami ketidakstabilan dari tahun 2014 sampai tahun 2017. Hasil perhitungan Rasio return on total asset (ROA)/return on investment (ROI) dapat dilihat pada Tabel 14.

Tabel 14

Hasil perhitungan ROA / ROI pada 5 Perusahaan.

\begin{tabular}{|c|c|c|c|c|c|}
\hline \multirow{2}{*}{ No } & \multirow{2}{*}{$\begin{array}{c}\text { Kode } \\
\text { Emiten }\end{array}$} & 2014 & 2015 & 2016 & 2017 \\
\cline { 3 - 6 } & AALI & $14 \%$ & $3 \%$ & $9 \%$ & $8 \%$ \\
\hline 1 & TLKM & $15 \%$ & $14 \%$ & $16 \%$ & $16 \%$ \\
\hline 2 & TL & $40 \%$ & $37 \%$ & $36 \%$ & $38 \%$ \\
\hline 3 & UNVR & $40 \%$ & $9 \%$ & $10 \%$ & $10 \%$ \\
\hline 4 & MNCN & $14 \%$ & & \multicolumn{4}{|c|}{ Tahun } \\
\hline 5 & ADHI & $1 \%$ & $0,1 \%$ & $2 \%$ & $2 \%$ \\
\hline
\end{tabular}

Sumber data : Data diolah.

Return on Investment (ROI) merupakan kunci ukuran kinerja pada pusat investasi. Pusat investasi adalah pusat pertanggungjawaban dalam sebuah organisasi yang mengawasi pendapatan, biaya dan dana investasi. Ini merupakan keuntungan yang kinerjanya dinilai dengan dasar hasil pengembalian yang diberikan oleh modal yang ditanam. Perhitungan ROI adalah NOPAT dibagi Total Aset (Total Aktiva). Hasil perhitungan tersebut dianalisa dengan menganalisa laporan keuangan yang mempunyai arti yang sangat penting sebagai salah satu teknik analisa keuangan yang bersifat menyeluruh (komprehensif).
3. Rasio Pengembalian Modal (Return On Net Worth)

Berdasarkan hasil perhitungan Tabel 14, maka dapat dilihat efektivitas perusahaan dalam memanfaatkan kontribusi pemilik atau menggunakan sumber-sumber lain untuk kepentingan pemilik. Perlu diingat rasio ini bukan pengukur return pemegang saham yang sebenarnya akan tetapi rasio pengembalian modal yang membandingkan antara laba bersih dengan modal pemilik. Hasil perhitungan return on net worth dapat dilihat pada Tabel 15. 
Tabel 15

Hasil perhitungan Return On Net Worth

\begin{tabular}{|c|c|c|c|c|c|}
\hline \multirow{2}{*}{ No } & \multirow{2}{*}{$\begin{array}{c}\text { Kode } \\
\text { Emiten }\end{array}$} & 2014 & 2015 & 2016 & 2017 \\
\cline { 3 - 6 } & AALI & $22 \%$ & $6 \%$ & $12 \%$ & $11 \%$ \\
\hline 1 & TLKM & $25 \%$ & $25 \%$ & $28 \%$ & $29 \%$ \\
\hline 2 & UNVR & $125 \%$ & $121 \%$ & $127 \%$ & $137 \%$ \\
\hline 3 & MNCN & $20 \%$ & $13 \%$ & $16 \%$ & $16 \%$ \\
\hline 4 & MDHI & $7 \%$ & $1 \%$ & $6 \%$ & $9 \%$ \\
\hline 5 & A &
\end{tabular}

Sumber data : Data diolah.

Kesimpulan dari analisi laporan keuangan 5 perusahaan yang bertahan di LQ45 selama 4 tahun yaitu dari tahun 2014 sampai dengan tahun 2017,menunjukkan bahwa perusahaan PT. Telekomunikasi Indonesia Tbk (TLKM) memiliki kestabilan pertumbuhan yang baik bila dibandingkan dengan 4 perusahaan yang lainya.

\section{KESIMPULAN DAN SARAN}

A. Kesimpulan

1. Perusahaan Indeks LQ45 yang teridentifikasi sebagai perusahaan yang bertahan dalam periode Agustus tahun 2014 sampai dengan July tahun 2017 ada 36 perusahaan diantaranya 5 perusahaan yaitu PT Astra Argo Lestari Tbk (AALI), PT Telekomunikasi Indonesia (Persero) Tbk (TLKM), PT Unilever Indonesia Tbk (UNVR), PT Media Nussantara Citra Tbk (MNCN), PT Adhi Karya (Persero) Tbk.

2. Kinerja keuangan perusahaan Indeks LQ45 dalam kondisi 4 tahun terakhir berdasarkan laporan keuangan tahunan dapat dilihat sebagai berikut;

a. PT Telekomunikasi Indonesia Tbk (TLKM) berada pada posisi tertinggi, sedangkan yang berada pada posisi terendah adalah PT Adhi Karya (Persero) Tbk (ADHI) berdasarkan rata - rata laporan laba rugi dengan kondisi pertumbuhan per tahun sebesar $9 \%, 22 \%, 12 \%$ dan $-82 \%, 119 \%$, $56 \%$..

b. Berdasarkan rata - rata NOPAT yang berada pada posisi tertinggi adalah PT Telekomunikasi Indonesia Tbk (TLKM), sedangkan yang berada pada poisisi terendah adalah PT Adhi Karya (Persero) Tbk (ADHI) dengan kodisi pertumbuhan per tahun sebesar 9\%, 25\%, 12\% dan $89 \%, 2819 \%, 64 \%$.

c. Berdasarkan rata - rata kewajiban (hutang) yang menempati posisi paling tinggi adalah PT Telekomunikasi Indonesia Tbk (TLKM), sedangkan yang berada pada poisisi yang terendah adalah PT Adhi Karya (Persero) Tbk. Dengan kondisi pertumbuhan per tahun sebesar 33\%, 2\%, $17 \%$ dan $5 \%,-3 \%, 200 \%$.

d. Berdasarkan rata - rata Modal (Ekuitas Pemilik) yang berada paada posisi tertinggi adalah PT Telekomunikasi Indonesia Tbk (TLKM) sedangkan yang berada pada poisisi terendah adalah PT Adhi Karya (Persero) Tbk. Dengan kondisi pertumbuhan per tahun sebesar $11 \%, 12 \%, 10 \%$ dan $11 \%, 221 \%, 8 \%$.

e. Berdasarkan rata - rata Total Aset (Aktiva) yang berada pada posisi tertinggi adalah PT Telekomunikasi Indonesia Tbk 
(TLKM) sedangkan yang berada pada poisisi terendah adalah PT Media Nusantara Citra Tbk (MNCN). Dengan kondisi pertumbuhan per tahun sebesar $18 \%, 8 \%, 11 \%$ dan $15 \%, 83 \%$, $41 \%$.

3. Kinerja setiap perusahaan berdasarkan rata - rata Return On Total Asset (ROA) / Return On Investment (ROI) dalam 4 tahun terakhir, perusahaan yang berada pada posisi tertinggi dengan nilai sebesar 0,377 adalah perusahaan PT Unilever Indonesia Tbk (UNVR), sedangkan yang berada pada posisi terendah adalah PT Adhi Karya (Persero) Tbk (ADHI) dengan nilai sebesar 0,012. Kondisi pertumbuhan per tahun pada perusahaan UNVR sebesar $-7 \%,-5 \%$, $6 \%$, sedangkan kondisi pertumbuhan per tahun pada perusahaan ADHI adalah sebesar $-91 \%, 1494 \%, 16 \%$.

B. Saran

a. Sebaiknya Bursa Efek Indonesia (BEI) membuat suatu standar pembuatan laporan keuangan dari perusahaan yang tergabung dalam LQ45 agar ada kesamaan dalam laporan keuangan berdasarkan time series ( 6 bulan atau tahunan) untuk member kemudahan kepada perusahaan - perusahaan maupun para investor dan calon investor (masyrakat yang mau berinvestasi).

b. Bagi pengguna laporan keuangan : Return On Total Asset / Return On Investment sebagai salah satu rasio profitabilitas dalam laporan keuangan, harus mendapat perhatian yang lebih dari pada sebelumnya, karena ternyata memiliki pengaruh terhadap return.

\section{DAFTAR PUSTAKA}

D, Prastowo Dwi. (2015). Analisis Laporan Keuangan. Yogyakarta: UPP STIM YKPN

Fahmi, Irham. (2013). Pengantar Manajemen Keuangan. Bandung: Alfabeta

Fahmi, Irham. (2015). Pengantar Teori Portofolio dan Analisis Investasi. Bandung: Alfabeta

Gitman, Lawrence J., Zutter. J chad. (2012). Principles of Managerial Finance. 13 th edition. Pearson Education LimitedSubramanyam, K.R. 2017 "Analisisi Laporan Keuangan”, Edisi Kesebelas Cetakan Pertama, Penerbit: Salemba Empat, Jakarta.

Sukamulja, Sukmawati. 2017 Pengantar Pemodelan Keuangan Analisis dan Pasar Modal", Penerbit: ANDI, Yogyakarta.

Supranto, M.A, APU, J. Februari 2004 "Statistik Pasar Modal Keuangan dan Perbangkan", Edisi revisi Cetakan Kedua, Penerbit : Rineka Cipta, Jakarta.

www.analis.co.id

www.bisnisinvestasisaham.com 